\title{
Improve Students' Narrative Writing Achievement Through Film at SMA NEGERI I PALIPI
}

\author{
Sondang Manik ${ }^{1} \&$ Jernih Donda Sinurat ${ }^{1}$ \\ ${ }^{1}$ HKBP Nommensen University, Indonesia \\ Correspondence: Sondang Manik, English Department, Language and Art Faculty, HKBP Nommensen \\ University, Medan, North Sumatra, Indonesia. E-mail: sondang_man1k@yahoo.com
}

Received: March 1, 2015 Accepted: March 20, 2015 Online Published: March 29, 2015

doi:10.5539/ijel.v5n2p172 URL: http://dx.doi.org/10.5539/ijel.v5n2p172

\begin{abstract}
This study attempted to improve students' English Narrative writing achievement through Film. The objective of study was to find out whether film can improve students' achievement in writing Narrative Paragraphs. This study was conducted by applying classroom action research which was done in 6 meeting of their English subject. The subject of this study was the second year students (XI -IPA - 2) of SMA Negeri 1 Palipi - Samosir Indonesia. One class was taken as the subject of the study. The number of the students was 30 students. The data of this research were obtained in two cycles, namely cycle 1 and cycle 2. Each cycle consisted of the four steps of an action Research: planning, action, observation and reflection. The instrument for collecting data used writing test from students' paper writing to write the film talk about as writing tests for the quantitative data and used diary notes, questionnaire sheet, observation sheet and interview for the qualitative data. Based on the writing test result, the students' score kept improving in every test. The findings indicated that the using of film as a media of learning improved students' writing achievement. The students' score significant was improved; the mean of second cycle i.e. 84.3 was higher than the mean of the first cycle i.e. 76.1. Based on diary notes, questionnaire sheet, observation sheet and interview, it was found that teaching learning process ran well. The conclusion was that using of film as a media of learning improved students' writing achievement.
\end{abstract}

Keywords: teaching media, narrative writing, learning process

\section{Introduction}

In the country where English as a foreign Language, writing in English is not easy for students. Writing is a process of putting thought, ideas, opinions, experiences, events, and histories such as writing letters, notes, shopping list, etc. According to Atwan and Forrer (1986, p. 91), writing can be as one way of expressing our feelings. Writing can also be a hobby to spend our time, but finally in this modern life, people can get money from doing their writing, like a journalist, novelist, or script writer. As Albee in Atwan and Vesterman (1987, p. 2) states that writing is to find out what we are thinking about.

According to Hyland (2002, p. 1), writing is the evidence our personal experience and we can be evaluated by reading our own writing. The purpose of writing, then the increased complexity of its context of use and diverse background and needs of those wishing to learn, all push the study of writing into wider frameworks of analysis and understanding.

Based on the writer's observation and interview results upon English teachers and students in class X TKR1 during attending PPL at SMK Citra Harapan Percut Sei Tuan, most of them said that it was so bored in writing session. The students usually complained, when they are asked to write something. It was different for them to find out, generate and translate the ideas in their brain into written language. Another factor that made learning writing in English was so bored because there are too many genre; they are narrative, descriptive, expository, argumentative, and persuasive. And also every genre of writing has different characteristics, namely, generic sosial function, structure and lexical grammatical features.

The failure of the students in writing was likely to happen because of media used by the teacher during teaching and learning process. Media is proven can increase the students' curiously to write everything in their mind. Therefore, it is important for English teacher to used various kinds of methods, techniques, strategies, and media. The teacher should not just tell the subject or materials and force the students to memorize or do their activities 
because it can make the students not interested their lessons, but teachers need to improve their way of teaching by using a media. There are many examples of media such as, song, picture, photograph, film or movie. In this study, the writer interested Film as a media for students to improve their writing skill especially in Narrative text. Film is an audio visual of story telling. Audio visual media is the media which can be heard and seen. They are television, film. This media can be used to teach a story, the events in the other place and the students are asked watch to them. It is supported by the research result Darwanto (2007, p. 101) used that "audio visual media can improved effective and efficient in process learning and used audio visual media like film or movie can improve teaching efficient 20\%-50\%". Three kinds of film in this media using which can make students more enjoyable in the learning process. Narrative means tells a story or account. It is an interesting writing for students because they could share their idea, opinion, imagination, and own experience, by their own words, like writing in a Film actually. The writer chooses narrative remembered that text books of students in Senior High School are consisting of narrative, generally.

The researcher conducts a research entitled "Improving Students' Narrative Writing achievement through Film".

The research question is "Does the use of Film significantly improve the students' narrative writing?"

There are some types of writing that should be mastered by students, such as descriptive, narrative, argumentative, persuasive, etc. In this study the writer focused on narrative writing on legends and used Film as audiovisual media.

The findings of the study are expected to be useful for English teachers to improve their way of teaching narrative paragraphs by using Film, other researchers to do further research and also whoever wants to improve the teaching quality of learning result through this Film (media).

\subsection{Assumption}

The basic assumptions of this paper comprise first the writer said the use of "film" as a media of teaching learning process and the students will be interested to learn about Narrative Writing; Second, the students feel that they will easily understand what is the Narrative Writing; Last, with film as a media of learning, the students will get the new way to write in English language text effectively and right.

In supporting the idea of research, theories are needed to explain some concept or term applied in the research. The terms must be clarified to avoid confusion. The research presents the discussion in some theories related to this study in order to strenghten this study. The research follows some theories as; Hornby $(1995$, p. 8), Harmer (2004, p. 33), Hayes (1996, p. 5), in Weige (2002, p. 19), Hyland (2002), etc.

\subsection{The Defenition of Key Terms}

It is crucial for the researcher and the readers to recognize the definition or the meaning of title of this research in order to make easier for the researcher in analyzing and understanding the problem deeply. Followings are the theories that will be discussed in this research.

1) Improving or Improve as a verb is making or become better: "efforts to improve, Develop or increase in mental capacity by education or experience".

2) Narrative is a type of writing which tells an event or process chronologically in certain time.

3) Narrative Writing is writing that tells a story, whether true or fictional.

4) Film, also called a movie or motion picture, is a series of still images on a strip of plastic which, when run through a projector and shown on a screen, creates the illusion of moving images.

5) SMA NEGERI 1 PALIPI is One Senior High School in Samosir Island, the place where the writer has done the research.

\section{Research Design}

This study was conducted by applying Classroom Action Research. Kemmis in Ismawati $(2011$, p. 49) states that action research is a form of self reflective enquiry undertaken by participants in social (including educational) situations in order to improve the rationality and justice of (a) their own social or educational practices, (b) their understanding of these practice, and (c) the situations in which the practices are carried out. Action research is an observation of an activity that appears consciously in a class. This is why the term "action" will use for this method of research.

Action research is a framework for problem-solving research, where there is collaboration between researches with the client in achieving goals. Wallace $(1998$, p. 18) states that classroom action research is different from more the conventional types of the research. It will focused on individual of small group professional practice. 
The subject of this research was students of class XI-IPA2 SMA NEGERI 1 PALIPI, Samosir, Academic Year 2012/2013.

Quantitave and qualitative research data was used in this research. The instrument for collecting quantitave data was by administering writing test. Students' were asked to write a narrative paragraph through watching Film. Qualitative data were gathered by turning Film, observation, questionnaire, and interview.

Diary Notes

It was used to record everything of the observation during the action.

\section{Observation Sheet}

It was used by the researcher to observe the students in identifying all condition that happened during teaching learning process. It was done at the ending of cycle one and cicle two.

\section{Questionnaire Sheet}

It was used to measure the level of students' activities during teaching learning process and know the respond and perception of the students about Film sequences as a media to improve their writing achievement. It was given to the students before giving the second test as the last test.

\section{Interview}

Interview was done after doing the second test. It was used to know whether the students got the score from the second test balanced with what they have state on the questionnaire sheet.

\section{The Procedure of the Research}

The procedure of the research was conducted within two cycles. According to Hornby (1974, p. 215), cycle are the series of events taking place in a regulary repeated order.

In this study, cycle one consists of four meetings including identification in the first meeting in order to get the background situation of teaching-learning process. So the first step began in the meeting.

\section{Cycle I}

The procedure of the first cycle can be seen as follows:

1. Planning

There were many activities that will done in planning, they are:

1) Prepare lesson plan;

2) Prepare the teaching material of narrative writing;

3) Prepare the instrument to record and analyze the data, such as diary notes, observation sheet, questionaire sheet and interview sheet;

4) Prepare the facilities and media that will be used as work sheet;

5) Plan and design the application model and procedure of teaching and learning method.

\section{Action}

Action is the process of the implement of plan. The activities are:

1) The writer opened the class and then called their name one by one;

2) The writer explained the defenition and importance of writing;

3) The writer explained about writing and types of writing;

4) The writer gave the students question about topic;

5) Teacher and the students answered the question together;

6) Give students question about the topic;

7) At last give the students questionanaires.

\section{Observation}

Observation is the purpose to find out the information of action, such as the teacher and students' attitudes, class events and climate during the teaching learning process. Thus, observation is done through by diary notes and observation sheet. Diary notes focus on students' activities. Every activities of students related to the scenario of the teaching and learning process will put on the diary note. Observation focusing on teacher and students' 
attitude and the condition of class during teaching learning process will be done. There are many things that should be observed as follow:

1) Many students didn't know how to write a narrative text and were not serious in writing narrative text;

2) Many students made noise in teaching learning process;

3) The students were not serious in doing the task, and

4) Then writer didn't admonish the students who could not control their voice to be quite.

\section{Reflection}

Reflecting is the feedback process for of the action, which has been done before. Reflection is used to help the teacher to make the decisions. Reflection has evaluative aspects to evaluate the effect of spacious issue and suggest the way to handle it.

In this phase, the research reflect everything that had been done before. The reflecting process will base on the data: written test and observation sheet.

\section{Cycle II}

\section{Planning}

Based on result of students' work in previous cycle and diary notes, the weakness of the students has been known. So, in this cycle the writer will try to improve it in learning process. The writer prepares lesson plans, some sample of narrative writing and the interesting text related recount.

\section{Action}

The teacher will explain about narrative writing briefly, explain the Film like Legenda Film, and then ask the students to choose one topic that related to their experience of watching legenda film. Brain storming the topic that has been chosen, and then ask students to do the tasks individually.

\section{Observation}

The purposed of observation is to find out information of action, such as students' attitude, behaviour and activities while giving action even the obstacles that happen to be noted in writer diary. The observer will observe the whole teaching and learning in the classroom.

\section{Reflection}

The writer will evaluate the result of the students' score and result of the observation, and then the writer will stop the research if they find students' achievement in narrative writing.

\section{- The Scoring System}

To collect the data, the writer will give the scores ranging from 0 to 100 . There were some important indicators to consider. Heaton as quoted by Tambunan stated that are five indicators in writing test; they are content, organization, vocabulary, language use and mechanics.

\section{a. Content}

The score of the content depends on the students' ability to write their ideas and information in logical sentence form.

\section{b. Organization}

The organization refers to the students' achievement in writing the ideas and information in good logical order. The topic and supporting sentences are clearly stated.

\section{c. Vocabulary}

Vocabulary refers to the students' achievement to use synonym, prefix and suffix correctly

\section{d. Language}

Language refers to the students' ability in writing the sentence, simple complex, and compound sentences correctly and logically. It also refers to the ability to use agreement in the sentences and some other words such as noun signal.

\section{e. Mechanics}

Mechanism refers to the students' ability to use words' function and spelling appropriately; paragraph and text can be read correctly. 


\section{- Technique of Analysing Data}

The data are analized by using of the following steps:

To know the mean of students' score for each cycle, the writer applies the following formula:

$$
\bar{X}-\frac{2 x}{N}
$$

Where $: \bar{X}=$ The mean of the students

$\Sigma \mathrm{X}=$ the total score

$\mathrm{N}=$ the number of the students

The score percentage of each cycle will be calculated by using this formula

$$
P=\frac{R}{T} \times 100 \%
$$

Where $: \mathrm{P}=$ The percentage of the students

$\mathrm{R}=$ the number of the students who got score $\geq 75$

$\mathrm{T}=$ the number of the students who did the test.

\section{- Procedures of Analyzing the Data}

The procedure of analyzing data are:

1) Collect the data from the scoring of the class;

2) Tabulate the score from the lowest to the highest;

3) Compare the sudents' score between cycle I and cycle II;

4) Calculate the percentage of the students' score;

5) Make the conclusion.

\section{Data Analysis}

\subsection{The Quantitative Data}

The Quantitative data was taken from the students' writing test result. There were three writing results which were gotten in 3 meetings. In the first meeting, the writer gave the students the writing test I, that was to write narrative paragraphs with the theme "Film: Malin Kundang". In the next meeting, the writer gave the students the writing test II that was to write narrative paragraphs with the theme "The Legend of Lake Toba" and the last meeting, the writer gave the students the writing test III that was to write narrative paragraphs with the theme "The Life of Fy".

The analysis of the Quantitative data can see that the improvement of students' mean kept growing from the pre-test until the post test of cycle 2. In the writing test I that was to write narrative paragraphs with the theme "Film: Malin Kundang", the total score of students in writing narrative paragraph was 2283 and the number students who took the test were 30 (table 1).

In writing test II that was to write narrative paragraphs with the theme "The Legend of Lake Toba" the total score of students in writing in narrative paragraphs was 2415 and the number of students who took the test here were 30 (table 2).

In writing test III that was to write narrative paragraphs with the theme "The Life of Fy", the total score of students in writing narrative paragraph was 2531 and the number $\mathrm{f}$ students who took the test were 30 (table 3 ). 
Table 1. The students' score from writing test I

\begin{tabular}{|c|c|c|c|c|c|c|c|}
\hline No & STUDENTS' INITIAL & $\mathbf{C}$ & $\mathbf{O}$ & $\mathbf{V}$ & $\mathbf{L}$ & M & WRITING TEST \\
\hline 1 & AS & 20 & 15 & 16 & 20 & 4 & 75 \\
\hline 2 & ASN & 20 & 14 & 14 & 18 & 4 & 70 \\
\hline 3 & CAS & 24 & 15 & 16 & 20 & 4 & 79 \\
\hline 4 & DM & 24 & 15 & 12 & 19 & 5 & 75 \\
\hline 5 & DG & 20 & 20 & 20 & 20 & 5 & 85 \\
\hline 6 & DS & 19 & 14 & 13 & 20 & 4 & 70 \\
\hline 7 & ES & 20 & 20 & 15 & 21 & 4 & 80 \\
\hline 8 & ESS & 19 & 15 & 12 & 20 & 4 & 70 \\
\hline 9 & EPTS & 20 & 20 & 15 & 21 & 4 & 80 \\
\hline 10 & EES & 20 & 15 & 10 & 15 & 3 & 73 \\
\hline 11 & GS & 19 & 12 & 11 & 15 & 3 & 60 \\
\hline 12 & HS & 25 & 15 & 19 & 19 & 3 & 81 \\
\hline 13 & IRP & 18 & 19 & 15 & 16 & 4 & 72 \\
\hline 14 & LS & 18 & 18 & 17 & 18 & 4 & 75 \\
\hline 15 & LLS & 20 & 16 & 19 & 20 & 5 & 80 \\
\hline 16 & LHS & 18 & 15 & 17 & 20 & 3 & 73 \\
\hline 17 & LCS & 17 & 16 & 17 & 17 & 3 & 70 \\
\hline 18 & MS & 22 & 15 & 18 & 20 & 5 & 80 \\
\hline 19 & NIS & 18 & 18 & 18 & 21 & 4 & 79 \\
\hline 20 & OS & 22 & 15 & 18 & 20 & 5 & 80 \\
\hline 21 & PP & 19 & 17 & 20 & 18 & 5 & 79 \\
\hline 22 & RS & 19 & 17 & 17 & 18 & 3 & 74 \\
\hline 23 & RSS & 20 & 16 & 16 & 19 & 4 & 75 \\
\hline 24 & SS & 21 & 17 & 17 & 20 & 5 & 80 \\
\hline 25 & SDTS & 22 & 17 & 18 & 20 & 5 & 82 \\
\hline 26 & $\mathrm{TS}$ & 20 & 18 & 18 & 20 & 4 & 80 \\
\hline 27 & TFP & 23 & 16 & 17 & 20 & 5 & 81 \\
\hline 28 & USDMS & 19 & 17 & 15 & 19 & 4 & 75 \\
\hline 29 & VS & 18 & 15 & 16 & 18 & 3 & 70 \\
\hline \multirow[t]{3}{*}{30} & YR & 20 & 17 & 18 & 20 & 5 & 80 \\
\hline & TOTAL & & & & & & 2283 \\
\hline & MEAN & & & & & & 76.1 \\
\hline
\end{tabular}


Table 2. The students' score from writing test II

\begin{tabular}{|c|c|c|c|c|c|c|c|}
\hline \multirow{2}{*}{ No } & \multirow{2}{*}{ STUDENTS' INITIAL } & $\mathbf{C}$ & $\mathbf{O}$ & $\mathbf{V}$ & $\mathbf{L}$ & $\mathbf{M}$ & \multirow{2}{*}{$\begin{array}{c}\text { WRITING TEST } \\
\text { II } \\
\end{array}$} \\
\hline & & & & & & & \\
\hline 1 & AS & 25 & 15 & 18 & 21 & 4 & 83 \\
\hline 2 & ASN & 20 & 20 & 20 & 16 & 4 & 80 \\
\hline 3 & CAS & 22 & 17 & 18 & 20 & 5 & 82 \\
\hline 4 & $\mathrm{DM}$ & 21 & 17 & 17 & 20 & 5 & 80 \\
\hline 5 & DG & 26 & 20 & 20 & 25 & 5 & 90 \\
\hline 6 & DS & 18 & 15 & 18 & 20 & 2 & 73 \\
\hline 7 & ES & 20 & 15 & 16 & 20 & 4 & 79 \\
\hline 8 & ESS & 20 & 15 & 15 & 18 & 4 & 72 \\
\hline 9 & EPTS & 28 & 18 & 20 & 22 & 5 & 93 \\
\hline 10 & EES & 25 & 15 & 18 & 21 & 4 & 83 \\
\hline 11 & GS & 18 & 10 & 10 & 9 & 3 & 65 \\
\hline 12 & HS & 23 & 18 & 17 & 20 & 4 & 82 \\
\hline 13 & IRP & 18 & 15 & 18 & 20 & 3 & 74 \\
\hline 14 & LS & 21 & 17 & 18 & 20 & 3 & 79 \\
\hline 15 & LLS & 23 & 15 & 16 & 21 & 4 & 80 \\
\hline 16 & LHS & 17 & 17 & 17 & 18 & 3 & 74 \\
\hline 17 & LCS & 21 & 17 & 17 & 20 & 5 & 80 \\
\hline 18 & MS & 20 & 20 & 20 & 20 & 5 & 85 \\
\hline 19 & NIS & 21 & 17 & 17 & 20 & 5 & 80 \\
\hline 20 & OS & 28 & 20 & 20 & 22 & 5 & 95 \\
\hline 21 & PP & 22 & 17 & 18 & 20 & 5 & 82 \\
\hline 22 & $\mathrm{RS}$ & 21 & 16 & 15 & 19 & 4 & 75 \\
\hline 23 & RSS & 21 & 17 & 17 & 20 & 5 & 80 \\
\hline 24 & SS & 25 & 15 & 16 & 21 & 4 & 81 \\
\hline 25 & SDTS & 25 & 20 & 20 & 21 & 4 & 90 \\
\hline 26 & TS & 21 & 15 & 14 & 18 & 4 & 77 \\
\hline 27 & TFP & 25 & 18 & 18 & 21 & 4 & 84 \\
\hline 28 & USDMS & 25 & 15 & 18 & 21 & 4 & 83 \\
\hline 29 & VS & 20 & 15 & 10 & 15 & 3 & 73 \\
\hline 30 & YR & 23 & 16 & 17 & 20 & 5 & 81 \\
\hline \multicolumn{2}{|r|}{ TOTAL } & & & & & & 2415 \\
\hline \multicolumn{2}{|r|}{ MEAN } & & & & & & 80.5 \\
\hline
\end{tabular}


Table 3. The students' score from writing test III

\begin{tabular}{|c|c|c|c|c|c|c|c|}
\hline \multicolumn{3}{|c|}{ STUDENTS' } & \multirow[b]{2}{*}{$\mathbf{O}$} & \multirow[b]{2}{*}{$\mathbf{V}$} & \multirow[b]{2}{*}{$\mathbf{L}$} & \multirow[b]{2}{*}{ M } & \multirow[b]{2}{*}{ WRITING TEST } \\
\hline No & INITIAL & $\mathbf{C}$ & & & & & \\
\hline 1 & AS & 22 & 15 & 18 & 21 & 4 & 80 \\
\hline 2 & ASN & 26 & 20 & 20 & 25 & 4 & 95 \\
\hline 3 & CAS & 26 & 16 & 17 & 21 & 4 & 84 \\
\hline 4 & $\mathrm{DM}$ & 26 & 15 & 18 & 21 & 4 & 84 \\
\hline 5 & DG & 26 & 20 & 20 & 24 & 5 & 95 \\
\hline 6 & DS & 20 & 14 & 14 & 18 & 4 & 75 \\
\hline 7 & ES & 23 & 15 & 18 & 21 & 4 & 81 \\
\hline 8 & ESS & 20 & 15 & 18 & 21 & 4 & 80 \\
\hline 9 & EPTS & 25 & 16 & 18 & 21 & 4 & 84 \\
\hline 10 & EES & 21 & 13 & 14 & 18 & 4 & 75 \\
\hline 11 & GS & 20 & 15 & 16 & 20 & 4 & 75 \\
\hline 12 & HS & 25 & 15 & 18 & 21 & 4 & 83 \\
\hline 13 & IRP & 20 & 16 & 17 & 21 & 4 & 80 \\
\hline 14 & LS & 25 & 15 & 18 & 21 & 4 & 83 \\
\hline 15 & LLS & 26 & 15 & 18 & 21 & 4 & 82 \\
\hline 16 & LHS & 25 & 15 & 18 & 21 & 4 & 83 \\
\hline 17 & LCS & 25 & 15 & 18 & 21 & 4 & 83 \\
\hline 18 & MS & 25 & 20 & 20 & 23 & 4 & 92 \\
\hline 19 & NIS & 26 & 20 & 20 & 23 & 4 & 93 \\
\hline 20 & OS & 26 & 20 & 20 & 23 & 4 & 93 \\
\hline 21 & PP & 20 & 15 & 18 & 21 & 4 & 80 \\
\hline 22 & $\mathrm{RS}$ & 25 & 15 & 18 & 21 & 4 & 79 \\
\hline 23 & RSS & 26 & 17 & 16 & 21 & 4 & 85 \\
\hline 24 & SS & 25 & 15 & 18 & 21 & 4 & 83 \\
\hline 25 & SDTS & 26 & 20 & 20 & 24 & 4 & 93 \\
\hline 26 & TS & 26 & 15 & 18 & 21 & 4 & 84 \\
\hline 27 & TFP & 26 & 15 & 18 & 21 & 4 & 84 \\
\hline 28 & USDMS & 25 & 15 & 18 & 21 & 4 & 83 \\
\hline 29 & VS & 25 & 20 & 20 & 25 & 3 & 95 \\
\hline 30 & YR & 26 & 17 & 18 & 21 & 4 & 85 \\
\hline \multicolumn{2}{|r|}{ TOTAL } & & & & & & 2531 \\
\hline \multicolumn{2}{|r|}{ MEAN } & & & & & & 84.3 \\
\hline
\end{tabular}


Table 4. The students' score from writing test I until writing test III

\begin{tabular}{|c|c|c|c|c|}
\hline \multirow[t]{2}{*}{ No } & \multirow[t]{2}{*}{ STUDENTS' INITIAL } & \multirow{2}{*}{$\begin{array}{c}\text { WRITING TEST } \\
\text { I }\end{array}$} & \multirow{2}{*}{$\begin{array}{c}\text { WRITING TEST } \\
\text { II } \\
\end{array}$} & \multirow{2}{*}{$\begin{array}{c}\text { WRITING TEST } \\
\text { III } \\
\end{array}$} \\
\hline & & & & \\
\hline 1 & AS & 75 & 83 & 80 \\
\hline 2 & ASN & 70 & 80 & 95 \\
\hline 3 & CAS & 79 & 82 & 84 \\
\hline 4 & $\mathrm{DM}$ & 75 & 80 & 84 \\
\hline 5 & DG & 85 & 90 & 95 \\
\hline 6 & DS & 70 & 73 & 75 \\
\hline 7 & ES & 80 & 79 & 81 \\
\hline 8 & ESS & 70 & 72 & 80 \\
\hline 9 & EPTS & 80 & 93 & 84 \\
\hline 10 & EES & 73 & 83 & 75 \\
\hline 11 & GS & 60 & 65 & 75 \\
\hline 12 & HS & 81 & 82 & 83 \\
\hline 13 & IRP & 72 & 74 & 80 \\
\hline 14 & LS & 75 & 79 & 83 \\
\hline 15 & LLS & 80 & 80 & 82 \\
\hline 16 & LHS & 73 & 74 & 83 \\
\hline 17 & LCS & 70 & 80 & 83 \\
\hline 18 & MS & 80 & 85 & 92 \\
\hline 19 & NIS & 79 & 80 & 93 \\
\hline 20 & OS & 80 & 95 & 93 \\
\hline 21 & PP & 79 & 82 & 80 \\
\hline 22 & $\mathrm{RS}$ & 74 & 75 & 79 \\
\hline 23 & RSS & 75 & 80 & 85 \\
\hline 24 & SS & 80 & 81 & 83 \\
\hline 25 & SDTS & 82 & 90 & 93 \\
\hline 26 & $\mathrm{TS}$ & 80 & 77 & 84 \\
\hline 27 & TFP & 81 & 84 & 84 \\
\hline 28 & USDMS & 75 & 83 & 83 \\
\hline 29 & VS & 70 & 73 & 95 \\
\hline 30 & YR & 80 & 81 & 85 \\
\hline & TOTAL & 2283 & 2415 & 2531 \\
\hline & MEAN & 76,1 & 80,5 & 84,3 \\
\hline
\end{tabular}

\subsubsection{Diary Notes}

The diary notes indicated that students' respect and response in learning writing narrative paragraphs by using film kept improving. Diary notes were used to record all things happened in the class based on what the writer can be seen as long as the teaching and learning process, So that by getting these diary notes, the writer has known the reflection and evaluation of using film in teaching writing.

\subsubsection{Observation}

The observation sheets indicated that most students were active during teaching and learning process which used media film. At the begining, the writer found difficult to begin and to manage the class because the students never used media in learning process, but at the last the student could create their narrative paragraphs by using media film. 
Table 5. Observation sheets

\begin{tabular}{|c|c|c|c|c|c|}
\hline \multirow[t]{2}{*}{ Focus } & \multirow[t]{2}{*}{ Topic } & \multicolumn{2}{|c|}{ Cycle I } & \multicolumn{2}{|c|}{ Cycle II } \\
\hline & & Yes & No & Yes & No \\
\hline \multirow{9}{*}{$\begin{array}{c}\text { The } \\
\text { students }\end{array}$} & 1. The students pay attention to the teacher's explanation. & & $\sqrt{ }$ & $\sqrt{ }$ & \\
\hline & 2. The students ask question to the teacher. & & $\sqrt{ }$ & $\sqrt{ }$ & \\
\hline & 3. The students do not make noisy in teaching-learning process & & $\sqrt{ }$ & $\sqrt{ }$ & \\
\hline & 4. The students answer the questions that given by the teacher. & & $\sqrt{ }$ & $\sqrt{ }$ & \\
\hline & 5. The students give good respon to the topic given. & & $\sqrt{ }$ & $\sqrt{ }$ & \\
\hline & 6. The students read the text and question actively and seriously. & & $\sqrt{ }$ & $\sqrt{ }$ & \\
\hline & $\begin{array}{l}\text { 7. The students write their own words on paper what the Film } \\
\text { tell about. }\end{array}$ & & $\sqrt{ }$ & $\sqrt{ }$ & \\
\hline & 8. The students feel interested in teaching learning process. & & $\sqrt{ }$ & $\sqrt{ }$ & \\
\hline & 9. The students do their writing test seriously. & $\sqrt{ }$ & & $\sqrt{ }$ & \\
\hline
\end{tabular}

\subsubsection{Interview}

Interview was done not only to the students but also to the English teacher. By doing interview, the writer has got information about the difficulties faced by student in writing narrative paragraph.

Interview with the teacher before the research was done (14 Mei - 2013).

$\mathrm{R}:$ Research

$\mathrm{T}:$ Teacher

$\mathrm{R}$ : Good morning Miss !

$\mathrm{T}$ : Good morning

$\mathrm{R}:$ How are you?

$\mathrm{T}$ : Fine

$\mathrm{R}$ : Ok, as we know, I have asked for permission to the headmaster to do the research here for two weeks . So I want to ask you as an English teacher for grade XI th, how many students are there in grade XI - IPA - 2 ?

$\mathrm{T}$ : Ok, now there are 35 students, especially for grade XI - IPA ,for grade XI - IPA 1, there are 35 students ,nd also XI-IPS 1 and XI - IPS 2 is 35 students.

$\mathrm{R}$ : So, there are four class in grade XI?

$\mathrm{T}$ : Four classes.

$\mathrm{R}$ : Right, could you tell me a little bit about them ,for example about their charactreristic in the class, how are they in they in the class? something like that.

$\mathrm{T}$ : Ok, right, about the students character in the class XI, because as we know, they are still young and some of them are till attractive, of course they must do something based what they do. So they don't think about what they do,what the influences of they do to the people or the tudents around them. So, you must know when you enter they class, you must see them what are the students look like, about their acting, the character, and maybe about how they speak. Ok, I think like that.

$\mathrm{R}$ : So,what about their ability in English Writing?

$\mathrm{T}$ : Ooh, the ability in the writing ,actually they still low especially in writing test. They cannot write well especially in English. When I teach them in front of the class, I Joined or i combine two languages for example I teach them in English, Ya! they don't understand about my explanation. So, I must combine the two languages to teach them. So ,the ability in English, I think they are still low.So, I must to talk with me something like that.

$\mathrm{R}$ : So, we can condude that their ability is still low and need to be improved .

$\mathrm{T}:$ Yes, youre right .

$\mathrm{R}$ : Ok, as we know we have Narrative writing topic for grade XI because they belongs to the syllabus . So, how do you teach that topic?

$\mathrm{T}:$ Oh, about the writing in Narative Paragraphs?

$\mathrm{R}$ : Yes, I mean do you use some kinds of strategy, method ,technique ormedia maybe?

$\mathrm{T}$ : Yes, of course, I must do something like this, I show the story text, and picture media. 
$\mathrm{R}$ : Ok, actually ask all these questions is to make me easier to face them later on in the class. So, actually in my research, I use film as a media in teaching Narrative Writing. Hopefully this strategy will help them to be able to know easy about Narrative, how to write a good Narrative Paragraphs. I think that's all that I want to know from you for now, thank you for your time to have an interview with me. Ok, see you on Thursday Miss.

$\mathrm{T}$ : Ok, see you.

\section{Interview sheet between the researcher and the students A ( $17 \mathrm{Mei}, 2013$ ).}

Researcher: "Is that true that writing paragraphs by film as media can help you to write paragraph narrative?"

Students A: "Yes, because in make a film we always interest write with narrative text."

Researcher: "Do you interested in writing narrative paragraphs throught film.

Students A: "Ya, karena film dapat membuat saya ingin tahu isi dan makna suatu cerita film yang ingin diceritakan kembali ke teks narrative.

Researcher: "Do you feel more active in teaching learning process by using film as media?"

Students A: "Ya, karena dalam film kita menggunakan media menonton dengan mata, bukan menggunakan media menulis kembali isi dari cerita film tersebut tersebut."

\section{Interview sheet between the researcher and the students B ( 17 Mei , 2013 ).}

Researcher: "Is that true that the using of film really helps you to write paragraph narrative?"

Students B: "Yes Miss, because I became know paragraph narrative well."

Researcher: "Do you feel interested in writing paragraph through film?

Students B: "Yes Miss, karena melalui film dapat membuat kita lebih nyaman disaat kita ingin tahu segala apa yang diceritakan film.

Researcher: "Did the Film make you more active in teaching learning process?"

Students: "Yes Miss, karena dengan menulis melalui film kita bisa terlatih dalam menulis, seperti apapun yang kita inginkan."

\section{Interview sheet between the ressearcher and the students C (Mei, 2013)}

Researcher: "Is that true that the using of film help you in writing narrative?"

Students C: "Ya, karena melalui film dapat mendorong saya dalam menulis."

Researcher: "Do you feel interested in writing through film?

Students C: "Ya, karena saya suka menulis cerita paragraph melalui film.

Resercher: "Is that true that the film can make you more active in teaching learning process?"

Studentd C: "Ya, karena saya lebih sering membuka kamus mengartikan film itu ke dalam bahasa inggris."

\section{Interview With the Teacher after the Research Was done ( 24 mei -2013)}

$\mathrm{R}$ : Research .

$\mathrm{T}:$ Teacher .

$\mathrm{R}$ : Well, what do you think about the strategy that I 've used Miss?

$\mathrm{T}$ : Oh , that's good. In the beginning I doubted that it will not work. I though that it will be difficult for them to be implemented . Narrative through film is not easy to be understood, but I see in fact, they could receive it and understand you mean. I'm sure that you also know about that. In my opinion, you are sucess in teaching this material and also in reating the strategy to your topic. So I can conclude that your research is success.

$\mathrm{R}$ : It's sound's nice, thank you very much Miss...

Actually at the first I had the same thought with you. I felt that it ill not work. But after I explained that and they could do what I mean, I was relatived, Miss.

T : Yeah, you're right. Maybe I use the same strategy with you in teaching Narrative Writing . i'm happy they can write well in writing Narrative Paragraphs through film.

$\mathrm{R}$ : Ok, thank you for your help during my Research.... 


\subsubsection{The Analysis of Questionnaire Sheet}

Based on Questionnaire sheets of 30 students, the result can be seen as follows:

Table 6 . The result table of questionnaire sheet

\begin{tabular}{|c|c|c|c|}
\hline \multirow[t]{2}{*}{ Statements } & \multicolumn{3}{|l|}{ Choices } \\
\hline & A & $\mathrm{B}$ & $\mathrm{C}$ \\
\hline 1. The using of Film as a learning media really helps me to write, especially in writing narrative. & $\begin{array}{l}100 \% \\
(30 \text { students })\end{array}$ & - & - \\
\hline $\begin{array}{l}\text { 2. I enjoy writing when the teacher applied the process by applying the using of Film as a learning } \\
\text { media. }\end{array}$ & $\begin{array}{l}100 \% \\
(30 \text { students) }\end{array}$ & - & - \\
\hline 3. I'm interest in teaching and learning process by applying the using of Film as a learning media. & $\begin{array}{l}100 \% \\
(30 \text { students })\end{array}$ & - & - \\
\hline 4. The Film as a learning media helps me in comprehending the elements of narrative text. & $\begin{array}{l}93 \% \\
(28 \text { students })\end{array}$ & $\begin{array}{l}7 \% \\
(2 \text { students })\end{array}$ & - \\
\hline 5. By applying the Film as a learning media, it is easier to understand narrative text. & $\begin{array}{l}93 \% \\
\text { (30 students) }\end{array}$ & $\begin{array}{l}7 \% \\
\text { (2 students) }\end{array}$ & - \\
\hline 6. The using of Film as a learning media can motivate me in learning narrative text. & $\begin{array}{l}100 \% \\
(30 \text { students) }\end{array}$ & - & - \\
\hline 7. The Film as a learning media provides effective discussion when we are in learning process. & $\begin{array}{l}100 \% \\
(30 \text { students })\end{array}$ & - & - \\
\hline $\begin{array}{l}\text { 8. The problem that usually faced in learning narrative paragraph can be solved through Film as a } \\
\text { learning media. }\end{array}$ & $\begin{array}{l}93 \% \\
(28 \text { students) }\end{array}$ & $\begin{array}{l}7 \% \\
(2 \text { students })\end{array}$ & - \\
\hline 9. Film as a learning media makes students more active in teaching and learning process. & $\begin{array}{l}93 \% \\
(28 \text { students })\end{array}$ & $\begin{array}{l}7 \% \\
(2 \text { students })\end{array}$ & - \\
\hline 10. The media which is used by the teacher is really helpful to construct the students' understanding. & $\begin{array}{l}100 \% \\
(30 \text { students })\end{array}$ & - & - \\
\hline
\end{tabular}

\subsection{The Data Analysis}

The data analysis can see that The improvement of the students' mean kept growing from the pre-test until in the post test of Cycle 2, that The students' mean scores of writing narrative paragraphs keep improving from the writing test I that is (76.1) to writing test II that is (80.5) it can be seen in table 1 the students' mean scores in the writing test II were higher than that in writing test III that is mean score (84.3). Then students' mean scores in the writing test II were higher than that in writing test I.

Table 7. The range of scores improvement

\begin{tabular}{lll}
\hline $\begin{array}{l}\text { The range students' score } \\
\text { improvement }\end{array}$ & Students' Initial Name & Total \\
\hline $20-25$ & ASN, VS \\
$15-19$ & GS & 2 \\
$10-14$ & DM, DG, ESS, LHS, LCS, MS, NIS, OS, RSS, SDTS & 1 \\
$5-9$ & AS, CAS, DM, DS, IRP, LS, USDMS, YR & 11 \\
$0-4$ & ES, EPTS, EES, HS, LLS, PP, SS, TS, TFE & 8 \\
\hline
\end{tabular}

The table 7 above showed that all students got the score improvement for the writing test I until writing test III even though the level of improvement was not the same for all students. They are students; ASN, VS, were the students who got the highest score improvement, they are range 20-25. Where ASN get score in Writing test I is 70 , to the second Writing test is 80 and the third Writing test is 95 . Also VS get score in Writing test I is 70, to the second Writing test is 73 and the third Writing test is 95 . (very high) during conducting the research, students ASN, VS, paid their attention the teacher' explanation about narrative. The student GS who get score in Writing test I is 60 , to the second Writing test is 65 and the third Writing test is 75, could only reach the range of score improvement. These student piad his attention to the teacher explanation. They were also interested to wacth the Film. They asked to the teacher if they did not understand it yet. At last of the writer, they really understood about the material and many of them got good scores. The range score 10-14 (medium) was got by students DM, DG, ESS, LHS, LCS, MS, NIS, OS, RSS, SDTS, they also get improvement value from the Writing test 1 until Writing test 3 . This is also the good range of score improvement but not all the students got the score good in 
this research. In the range of score improvement about 5-9 (average), there were 8 students who got this range, they are AS, CAS, DM, DS, IRP, LS, USDMS, YR. During research they also paid attention to what the teacher explained but they were not so seriously and were not as active as the students got higher range of score improvement.

The students AS, CAS, DM, DS, IRP, LS, USDMS, YR, could only the improvement in the range about 5-9 (low). For some meetings, these students did not give their attention and sometime they made a noisy and disturbed their other friends. However, they could get score improvement and even get score $\geq 80$. Eight last students ES, EPTS, EES, HS, LLS, PP, SS, TS, TFE, were the students who got the lowest improvement.

The students' score improvement in writing narrative paragraph through Film can be seen from the mean of students' score during the research. To know it, the writer applied the following formula:

$$
\bar{X}=\frac{2 \cdot x}{N}
$$

Where : $\bar{X}=$ The mean of the students

$$
\begin{aligned}
& \sum \mathrm{X}=\text { the total score } \\
& \mathrm{N}=\text { the number of the students }
\end{aligned}
$$

In the writing test I, the total score of students in writing narrative paragraph was 2283 and the number students who took the test were 30 , so the students' mean score was :

$$
\begin{aligned}
\bar{X} & =\frac{2290}{a 0} \\
& =76.1
\end{aligned}
$$

In writing test II, the total score of students in writing in narrative paragraphs was 2415 and the number of students who took the test here were 30 , so the students' mean score was :

$$
\begin{aligned}
\bar{X} & =\frac{24,15}{30} \\
& =80.5
\end{aligned}
$$

In writing test III, the total score of students in writing narrative paragraph was 2531 and the number $f$ students who took the test were 30 , so the students' mean score was :

$$
\begin{aligned}
\bar{X} & =\frac{2531}{30} \\
& =84.3
\end{aligned}
$$

The figures above showed that there was the improvement of the students' mean scores during the research. The students' mean score in the writing test II was higher than writing test I. The students' mean score in writing test III was the highest from all the students' mean score during the research. The students' mean score improved from $76.1,80.5$ to 84.3 .

The percentage of students who were success in learning was calculated by the following formula:

$$
P=\frac{R}{T} \times 100 \%
$$

Where :

$\mathrm{P}=$ The percentage of the students

$\mathrm{R}=$ the number of the students who got score $\geq 82$

$\mathrm{T}=$ the number of the students who did the test.

The percentage of students who were success in learning during the research could be seen as follow:

The percentage of students who were success in learning in writing test I

$$
\begin{aligned}
P 1 & =\frac{2}{30} \times 100 \% \\
& =6.66 \%
\end{aligned}
$$


The percentage of students who were success in learning writing test II

$$
\begin{aligned}
P_{2}= & \frac{12}{30} \times 100 \% \\
& =40.0 \%
\end{aligned}
$$

The percentage of students who were success in learning writing test III

$$
\begin{aligned}
\boldsymbol{P B}_{3} & =\frac{16}{30} \times 100 \% \\
& =53.33 \%
\end{aligned}
$$

Based on figure 2 above, it showed that percentage of students who were success in learning improved in each test. In writing test I there was only $6.66 \%$ (two students) in cycle 1 who got $\geq 82$. In writing test II in cycle 1 there was the improvement of percentage of students who got score $\geq 82$ that is $40.0 \%$ (12 students). In writing test III which was done in the cycle II, not all the students got the score $\geq 82$. Even though they which could not get score $\geq 82$, their score kept improving from writing test I until writing test III. Thus, it could be said that the use of Film as the media in teaching writing narrative paragraphs could improve students' achievement in writing narrative paragraph.

\subsection{Research Account}

This research was conducted in two cycles. Cycle I was done in three meetings.

\subsubsection{First Cycle}

The first cycle was done in three meetings. The detail procedure of first cycle was described was follow:

\section{1) Planning}

In planning, first of all , the writer investigated and formulated the problems which students found in writing narrative paragraphs. Then, the writer gave them test I namely to write narrative paragraph with the theme " The Film about Legends".

Next the writer prepared the leeson plan and media which were used in learning process. The instrument of collecting the data were diary notes, observation sheet, questionnaire and interview sheet.

\section{2) Action}

In this phase, the writer as the teacher applied the lesson plan which have arranged before. Then, the teacher explained the defenition about narrative, how to write narrative paragraph elements and linguistic features of narrative. Next the teacher gave them an example oof narrative paragraph.

After explaining narrative, teacher explained about simple past tense. Then the teacher played the Film about Legends. After watching the Film, the first teacher asked them to answer some question about Film. Next, they were asked to retell the story about the Film in order to remind them about the story. Finally, the teacher asked them to write in narrative paragraphs.

\section{3) Observation}

The result of observation showed that the teaching learning proccess run well. The situation was comfortable for teaching learning because the classroom was far from crowed place. But, some students were disturbeb their friends, the other students paid attention not only to explanation but also in writing their paragraph. The interaction between teacher and the students was well.

\section{4) Reflecting}

The reflecting was done to evaluate the teaching learning process. The success level of teaching learniing process in cycle increased before teaching learning paragraph using Film. The problem students in that research, they have problem in sentence not good. From the data, the writer decided to continue cycle II and to focus on grammar in order to get the better result.

\subsubsection{Second Cycle}

Based on the reflection of the first cycle, it needed to conduct the second cycle. This second cycle was intended to solve the problems found in the first cycle and to improve the students' skill in writing narrative paragraph. This cycle was also in three meetings. The detail procedure of the second cycle was described as fllows: 


\section{1) Planning}

In the planning of second cycle the writer still concentrated to the same concepts of idea in the cycle one but the preparation of this cycle was the same as the first cycle. The writer arranged the lesson plan, also prepared and choose Film which was familiar with the students. After watching the Film, they asked to retell the story about the Film. Finally, they were asked three paragraphs. The writer prepared the diary notes, observation sheets too.

\section{2) Action}

In this phase, the writer still used Film as the media in teaching writing narrative paragraphs. First, the writer explained about narrative more detailed and gave them example of narrative paragraphs. Then, teacher explained simple past tense more detailed. The procedures of implementing of this method were same as the first cycle.

\section{3) Observation}

The observation which was done in the second cycle showed that the most students were more active and enthusiastic than that it in first cycle. After knowing the result of their writing in the first cycle, the students tried to give their attention to the teacher explanation fully did what the teacher instructed to do. They were more enjoyable to writing test III because the movie have watched by them. The teacher was able to manage the class to the students participated in teaching learning process.

\section{4) Reflecting}

After evaluating the students writng test, the writer found that the students score improved. Based on the observation and writing score showed that most students had mastered writing narrative paragraph through Film. It coul be improved from the score percentage $f$ the students who got the score $\geq 82$ in cycle II $53.33 \%$. Based on the reflection of this cycle, the cycle of this research could be stopped because the students' achievement in writing narrative paragraph had been improved.

\subsection{The Research Finding}

The finding of this research have show that the use of Film is able to improve students' narrative writing achievement through Film. By using this media, the mean score in writing test I there was $6.66 \%$ (two students). In writing test II was $40.0 \%$ (12 students). In writing test III 53.33\%.

Besides it, the expression and excitement of the students also showed the improvement. It could be seen from the observation sheets and diary notes. All these data showed that meeting by meeting the students were active and excited during the teaching learning process based on the result of quantitative, qualitative data had been showed, it indicated that the use of Film as a media in teaching writing narrative paragraphs kept improving the students' achievement in writing narrative paragraph.

The conclusion is strengthen by the qualitative data that were taken from dyare notes, observation sheets, questionnaire and interview sheets supported that the students interest and understanding writing increased because they were enthusiasts and enjoy with the process of learning. They were also more active to participate in the process of learning.

\subsection{Discussion}

The using of Film as a media helped students to be easier in learning writing especially narrative paragrahs. Students were given the chance to express their own experience every day.

In tis study, we could find that all students got improvement for their score. Most of them got a very big improvement, but also some of them ust got a little improvement.

From the result of the test, we could find that all of students got the improvement; in fact most of them got a big improvement.

\section{From pre-test to cycle 1:}

- There were 8 students who got improvement 10-9 point or more (AS, CAS, DM, DS, IRP, LS, UDTMS, VR). It means that the students got the increasing 5-9 point or more after cycle 1 was done.

\section{From cycle 1 to cycle 2:}

- There were 11 students who got improvement 10-14 point or more (DM, DG, ESS, ES, LHS, LOS, MS, NIS, OS, RSS, SDTS).

From the pre-test up to cycle 2, we could find that some of the same students can get the improvement 10-14 point more. 


\section{From pre-test cycle 2:}

- $\quad$ There were 2 students who got a very big improvement 20 to 25 point or more (ASM, VS) student who got the improvement from 16 to 19 point (GS).

Based on the improvement of the students' score from pre-test to cycle 1 to cycle 2 , it could be concluded that writing through Film which the form similarity with narrative paragraphs were effective to use. Students interesting in writing through Film because they feel that were not in learning process but, just still expressing something to their book.

\section{Conclusions}

1) Arsyad state that media is one of the ways to make writing class more interesting is by using media when teacher is teaching and He said that the using of media can motivate the students and give some psychologies effect in learning process. From the two statements, it can be concluded that media is everything which can be used as tool and facilitate to get the goal in teaching learning process. There are so many media which can be used by the teachers in learning process, for instance photo, picture, flascard, etc.

2) Motion picture is a series of images that are projected into a screen to create the illution of emotion. Furthermore, motion pictures are also called movies, film or cinema, are one of the most popular forms of entertainment, that have people to immerse themselves in imaginary the world for a short period of time. But film or movies can also teach people about history, science, human behavior and any other subjects. Some film or movies combine entertainment with instruction, makes the learning process more enjoyable. The writer in here, choose Film as a media in learning process in class which can improve their writing in Narrative paragraph.

3) After analyzing the data, it was found that the students' score improved from writing test I until writing test III. It can be proved from the mean of students' score which kept increasing from the first test until the last. The students' mean score in writing test I is (76.1). The students' mean score in writing test II is (80.5). The students mean score from the writing test I to writing test II. In writing test I, there is only $6.66 \%$ students who got the score $\geq 82$ became $53.33 \%$.

Besides, after finishing cycle II, it was also found that the students did not find the problem and difficulties to understand and write narrative paragraphs anymore by using Film as media of learning. By watching Film, they were more interested to write narrative paragraphs and they got easier to write in good narrative paragraphs.

Based on the data, it can be concluded that Film as media of writing learning is effective to teach writing narrative paragraphs in class XI-IPA2 SMA NEGERI 1 PALIPI - SAMOSIR.

Thus, the Film as a media in teaching writing narrative paragraphs will help the students to be more interested in Writing.

\section{Suggestions}

The findings of this research showed that the use of Film could improve students' achievement in writing narrative paragraphs. Therefore, the following suggestions are offered:

1) English Students in a University especially English Students in HKBP Nommensen University are suggested to use this method in writing a paragraph. By applying Film as a media, the students will be find it is easier to compose the text and they will find the way to write English perfectly.

2) English teacher, it is better to use Film as a media in teaching writing narrative paragraphs to make students more interested and enjoyable in writing narrative paragraphs.

\section{References}

Arsyad, A. (1997). Media Pembelajaran. Jakarta: P.T Raja Grafindo Persada.

Atwan, R., \& Forrer, B. (1986). Why We Write: A Thematic Reader. New York: Seton Hall University.

Atwan, R., \& Vesterman, W. (1987). Effective Writing For The College Curriculum. New York.

Best, J. W. (1982). Research in Education. New Delhi: Prentice Hall.

Coffin, C., Curry, M. J., Goodman, S., Hewings, A., Lilis, T. M., \& Swann. J. (2003). Teaching Akademic Writing. England: Routledge.

Emzir. (2008). Metode Penelitian Pendidikan. Jakarta: T Raja Grafindo Persada.

Harmer, J. (2001). The practice of English Language Teaching. England. Pearson education limited. 
Harmer, J. (2004). How To Teach Writing. New York: longman Group.

Hornby, A. S. (1995). Oxford Advanced learner's Dictionary. New York: Oxford University Press.

Hyland, K. (2002). Teaching and Researching Writing. England: Pearson Education.

Ismawati, E. (2011). Metode Penelitian Pendidikan Bahasa dan Sastra. Jakarta: Yuma Pustaka.

Siahaan, S., \& Shinoda, K. (2008). Generic Text Structure. Yogyakarta: Graha Ilmu.

Siahaan, S., Napitupulu, S., \& Sipayung, K. (2008). Text Writing: Writing II Handouts.

Wallace, M. J. (1998). Action Research For Language Teachers. United Kingdom: Cambridge University Press.

Weigle, S. C. (2002). Assessing Writing. Cambridge: University Press. http://dx.doi.org/10.1017/CBO9780511732997

\section{Copyrights}

Copyright for this article is retained by the author(s), with first publication rights granted to the journal.

This is an open-access article distributed under the terms and conditions of the Creative Commons Attribution license (http://creativecommons.org/licenses/by/3.0/). 